\title{
QUEEN'S
UNIVERSITY
BELFAST
}

\section{Micro-mechanical analysis of the effect of ply thickness on the transverse compressive strength of polymer composites}

Arteiro, A., Catalanotti, G., Melro, A. R., Linde, P., \& Camanho, P. P. (2015). Micro-mechanical analysis of the effect of ply thickness on the transverse compressive strength of polymer composites. Composites Part $A$ : Applied Science and Manufacturing, 79, 127-137. https://doi.org/10.1016/j.compositesa.2015.09.015

\section{Published in:}

Composites Part A: Applied Science and Manufacturing

\section{Document Version:}

Peer reviewed version

\section{Queen's University Belfast - Research Portal:}

Link to publication record in Queen's University Belfast Research Portal

\section{Publisher rights}

Copyright 2015 Elsevier.

This manuscript version is made available under the CC-BY-NC-ND 4.0 license (http://creativecommons.org/licenses/by-nc-nd/4.0/), which permits distribution and reproduction for non-commercial purposes, provided the author and source are cited.

\section{General rights}

Copyright for the publications made accessible via the Queen's University Belfast Research Portal is retained by the author(s) and / or other copyright owners and it is a condition of accessing these publications that users recognise and abide by the legal requirements associated with these rights.

Take down policy

The Research Portal is Queen's institutional repository that provides access to Queen's research output. Every effort has been made to ensure that content in the Research Portal does not infringe any person's rights, or applicable UK laws. If you discover content in the Research Portal that you believe breaches copyright or violates any law, please contact openaccess@qub.ac.uk. 


\section{Accepted Manuscript}

Micro-mechanical analysis of the effect of ply thickness on the transverse compressive strength of polymer composites

A. Arteiro, G. Catalanotti, A.R. Melro, P. Linde, P.P. Camanho

PII:

S1359-835X(15)00336-X

DOI: http://dx.doi.org/10.1016/j.compositesa.2015.09.015

Reference: JCOMA 4060

To appear in:

$$
\text { Composites: Part A }
$$

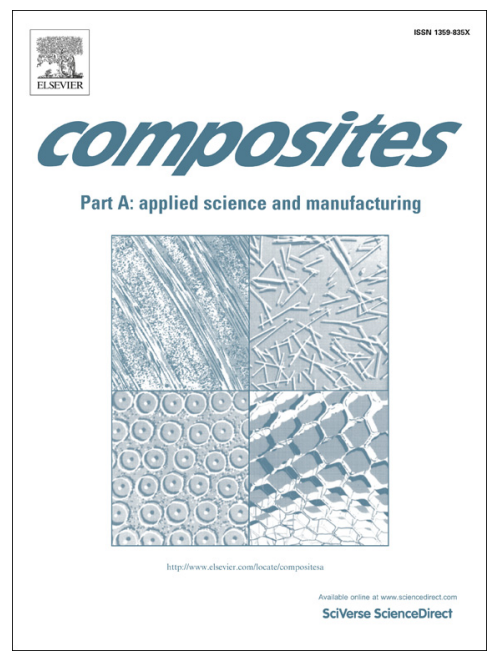

Received Date:

2 April 2015

Revised Date:

17 September 2015

Accepted Date:

21 September 2015

Please cite this article as: Arteiro, A., Catalanotti, G., Melro, A.R., Linde, P., Camanho, P.P., Micro-mechanical analysis of the effect of ply thickness on the transverse compressive strength of polymer composites, Composites: Part A (2015), doi: http://dx.doi.org/10.1016/j.compositesa.2015.09.015

This is a PDF file of an unedited manuscript that has been accepted for publication. As a service to our customers we are providing this early version of the manuscript. The manuscript will undergo copyediting, typesetting, and review of the resulting proof before it is published in its final form. Please note that during the production process errors may be discovered which could affect the content, and all legal disclaimers that apply to the journal pertain. 


\section{Micro-mechanical analysis of the effect of ply thickness on the transverse compressive strength of polymer composites}

A. Arteiro ${ }^{\mathrm{a}}$, G. Catalanotti ${ }^{\mathrm{a}, \mathrm{b}}$, A.R. Melro ${ }^{\mathrm{c}, \mathrm{d}}$, P. Linde $^{\mathrm{e}}$, P.P. Camanho $\mathrm{C}^{\mathrm{a}, \mathrm{b}, *}$

${ }^{a}$ DEMec, Faculdade de Engenharia, Universidade do Porto, Rua Dr. Roberto Frias, s/n, 4200-465 Porto, Portugal

${ }^{b}$ INEGI, Universidade do Porto, Rua Dr. Roberto Frias, 400, 4200-465 Porto, Portugal

${ }^{c}$ ISVOUGA - Instituto Superior de entre Douro e Vouga, Rua António de Castro Corte Real, Apartado 132, 4520-181 Santa Maria da Feira, Portugal

${ }^{d}$ CIDEM/ISEP - Instituto Superior de Engenharia do Porto - Instituto Politécnico do

Porto, Rua Dr. António Bernardino de Almeida, 431, 4249-015 Porto, Portugal

${ }^{e}$ AIRBUS Operations GmbH, Kreetslag 10, 21129 Hamburg, Germany

\section{Abstract}

A micro-mechanical model is used to study the effect of ply thickness on constrained $90^{\circ}$ plies subjected to transyerse compressive loading (in situ effect). For cross-ply sublaminates with conventional, standard-thickness $90^{\circ}$ plies, failure is dominated by fibre-matrix interface cracking and large localised plastic deformation of the matrix, forming a localised band in a plane that is not aligned with the loading direction. Ultra-thin plies show a dispersed damage mechanism, combining wedge cracking with ply fragmentation/separation. Moreover, a transverse crack suppression effect is clearly observed. To the authors' knowledge, it is the first time an in situ effect in transverse compression has been identified. When comparing the results of the micro-mechanical model with the predictions from analytical models for

\footnotetext{
*Corresponding author. Tel.: +351 225081753; fax: +351 225081445.

Email address: pcamanho@fe.up.pt (P.P. Camanho)
} 
the in situ effect, the same trends are obtained. These results also show that, for realistic ply thicknesses, these analytical models can be considered fairly accurate.

Keywords: A. Laminates, B. Transverse cracking, C. Micro-mechanics.

\section{Introduction}

The spread tow thin-ply technology $[1,2]$ is a recent technique which incorporates a pneumatic process where fibre tows are continuously and stably opened to produce flat and straight plies with dry ply thicknesses as low as $0.02 \mathrm{~mm}$. Laminates made of these ultra-thin plies have the potential to suppress both microcracking and delamination before ultimate failure, which results in an increasing interest by the scientific and industrial communities in this technology [3-25].

The improved fibre dispersion resulting from tow spreading has motivated the study of the effect of ply thinness on the mechanical response of unidirectional (UD) laminae. Amacher et al. [21] performed an extensive experimental characterisation of the mechanical response of thin-ply laminates, including testing of UD carbon fibre-epoxy composites with ply areal weights ranging from ultra-thin to very high grades, all produced from the same batch of fibre and matrix. No significant influence of the ply thinness on the elastic and strength properties of the UD composites was observed, except for longitudinal compression, where an enhancement of approximately $20 \%$ in average was observed. This enhanced compressive strength is attributed to the more uniform microstructure of spread tow thin plies. Optical micrographs presented by Amacher et al. [21] show that the microstructure 
of high-grade composites is fairly inhomogeneous, with varying fibre volume fraction along the microstructure due to fibre rearrangement and resin flow during the low-viscosity phase of the curing cycle. This heterogeneous microstructure promotes instabilities at the constituent level that may result in premature compressive failure of the laminae [21]. As the ply thickness decreases, a better uniformity of the microstructure is achieved, becoming practically homogeneous for the lowest grades, delaying the instabilities that conduct to fibre compressive failure, therefore increasing the compressive strength.

When very thin plies are embedded in multidirectional laminates, the thin-ply effect becomes particularly important. In this case, the constraining effect imposed by the neighbouring plies delays damage propagation in the matrix [21, 26], and the actual ply strengths are not only higher than those measured in UD coupons, but they reportedly increase with decreasing ply thickness [11, 27-35].

Experimental studies have shown that the longitudinal compressive and transverse shear strengths are affected by the presence of transverse microcracking [30]. If transverse microcracking is delayed, the strengths associated with other matrix-dominated failure mechanisms, such as wedge compressive fracture, may also increase due to the constraining effect imposed by adjacent plies. This can be addressed through the application of three-dimensional (3D) phenomenological failure criteria $[36,37]$. According to these models, when embedded in a multidirectional laminate, not only the transverse tensile and in-plane shear strengths ( $Y_{T}$ and $S_{L}$, respectively), calculated using e.g. the models proposed by Camanho et al. [33], but also the transverse 
compressive and transverse shear strengths $\left(Y_{C}\right.$ and $S_{T}$, respectively) are in situ properties. In addition, assuming that kink bands ${ }^{1}$ are triggered by localised matrix failure in the vicinity of misaligned fibres $[36,37]$, the in situ effect will also result in an increased longitudinal compressive strength in multidirectional laminated composites.

In a previous work [22], a micro-mechanical finite element (FE) model of a composite sublaminate was proposed to study the mechanics of the in situ effect observed on constrained plies subjected to transverse tensile loading. This micro-mechanical model consisted of a representative volume element (RVE) of a $90^{\circ}$ thin lamina in-between two homogenised $0^{\circ}$ plies. Random distributions of carbon fibres in an epoxy matrix, statistically equivalent to real distributions, were analysed using a 3D computational micro-mechanics framework, with a special focus on the elastic-plastic and damage constitutive behaviours of the matrix and on the response of the fibre-matrix interface. Varying the $90^{\circ}$ ply thickness, it was possible to assess its effect on the mechanical response of laminated composites.

The objective of this paper is to investigate whether there is an in situ effect for transverse compressive loads as predicted by some failure criteria $[36,37]$. In the absence of experimental information, a micro-mechanical model is used to study the in situ effect observed on constrained plies subjected to transverse compressive loading. Also, a comparison between the results of the micro-mechanical model and the predictions from the analytical models for the in situ effect based on Linear Elastic Fracture Mechanics

\footnotetext{
${ }^{1}$ Crack-like type of failure occurring in laminae subjected to compressive loadings in the fibre direction [38].
} 
(LEFM) [33] and phenomenological 3D failure criteria $[36,37]$ is presented with the aim of validating both modelling strategies.

\section{Micro-mechanical constitutive and finite element modelling}

An FE model of the thin-ply sublaminate is generated, consisting of three main parts: a micro-mechanical RVE of the $90^{\circ}$ ply, two adjacent homogenised $0^{\circ}$ plies, and the interfaces between the $90^{\circ}$ lamina and the homogenised plies [22]. The RVE of the $90^{\circ}$ ply includes a discrete representation of the fibres, matrix and interfaces between fibres and matrix.

A random distribution of carbon fibres is generated using a modification of the algorithm proposed by Melro et al. [39], with imposed fibre continuity along the faces perpendicular to the $y y$-direction for implementation of periodic boundary conditions (PBCs) - see figure 1 , where the $x x$-direction coincides with the longitudinal (fibre) direction of the discretised transverse ply (normal to the surface of the page), the $y y$-direction coincides with the in-plane transverse direction of the discretised transverse ply (horizontal direction), and the $z z$-direction coincides with the out-of-plane (through-thethickness) transverse direction (vertical direction). Unlike 3D random RVEs with PBCs for analysis of UD composites [39, 40], in the present study the entire thickness of the discretised transverse ply is explicitly represented, so its effect in the response of the sublaminate can be taken into account. The faces of the discretised transverse ply perpendicular to the $z z$-direction (top and bottom faces) will be connected to the homogenised outer plies, and, therefore, in the generation of the RVE, fibres are not allowed to intersect these faces. 
In the present study, the individual carbon fibres are considered transversely isotropic and linear-elastic [22]. Following Melro et al. [41], the diameter of the carbon fibres is the same in the entire RVE.

The epoxy resin is modelled using the plastic-damage material model proposed by Melro et al. [40]. This material model, implemented as an UMAT user subroutine [42], includes a paraboloidal yield criterion, defined as a function of the stress tensor and of the compressive and tensile yield strengths, and a non-associative flow rule, which allows for a correct definition of the volumetric deformation in plasticity. Figure 2 shows the hardening curves used in the plasticity model for both tension and compression. A thermodynamically consistent isotropic damage model, defined by a single damage variable, is used, where damage onset is defined by a damage activation function similar to the paraboloidal yield criterion, but using the final compressive and tensile strengths of the epoxy resin. To avoid damage localisation, the computed dissipated energy is regularised using the characteristic length of the FE and the fracture toughness of the epoxy resin [43].

The interfaces between fibres and matrix are modelled using cohesive elements $[22,41,42]$, defined by a bilinear traction-separation damage law. The onset of cohesive damage is mode dependent, and is defined by the corresponding strengths in mode I and mode II. The rate of damage progression is controlled by the critical energy release rate under pure and mixed modes, according to the Benzeggagh-Kenane (BK) law [44].

Different 3D RVEs of the thin-ply sublaminate are generated [39]. These include different random fibre distributions for the same RVE's size, which are analysed to assess the effect of microstructural randomness. The width of 
the RVEs of the thin-ply sublaminates along the $y y$-direction (see figure 1) is $0.200 \mathrm{~mm}$. This was defined to ensure the representativeness of the different RVEs analysed in the present work; in fact, it is important to note that the width of the RVEs should be defined in such a way that any diffuse damage, which might occur before a transverse crack has grown entirely through the thickness of the ply, can be captured [22]. In a compromise between the computational cost of the proposed models and the results obtained, it was observed that an RVE width of $0.200 \mathrm{~mm}$ was adequate to capture the diffuse damage occurring on the thinner transverse plies. However, due to the enormous computational cost of these models, the RVEs of the sublaminates with transverse ply thicknesses above or equal to $0.100 \mathrm{~mm}$ were modelled to accommodate approximately a single transverse crack, as in Ref. [22], reducing the total width of the RVEs to $0.120 \mathrm{~mm}$. As the transverse ply gets thicker, the size of the models becomes so large that they cannot be handled. On the other hand, it was observed that, for such transverse ply thicknesses, the diffuse damage, before transverse cracking grew through the thickness, was very limited (similarly to what was observed in Ref. [22] for transverse tension). Therefore, defining the width of the RVE such that a single transverse crack could be captured was sufficient to study the damage morphology and predict failure of the thicker transverse plies. By reducing the RVE width, from $0.200 \mathrm{~mm}$ to $0.120 \mathrm{~mm}$ for transverse ply thicknesses of $0.100 \mathrm{~mm}$ and above, was enough to capture transverse cracking and keep the computational cost of the models in reasonable values. It is recognised that the size of the RVE may affect the predicted material response, particularly during softening [41]; however, the analysis of the RVEs with thicker 
transverse plies is still important to accurately address the causes of matrix transverse compressive failure as the ply thickness changes.

The length of the micro-mechanical models ( $x x$-direction) is kept constant and approximately equal to two times the average element size of the mesh of the discretised transverse ply, or 0.2 times the fibre radius. A discretisation of two elements along the $x x$-direction was used. The authors believe this is the most suitable choice for the compromise between the computational cost of the present models and the quality of the results. Despite the increased computational cost of the 3D modelling approach, the flexibility of the present computational micro-mechanics framework to predict the mechanical response of UD composites and sublaminates subject to general 3D loading conditions motivates its employment in the present study.

The homogenised $0^{\circ}$ plies, which simulate the mesoscopic elastic behaviour of the surrounding laminae, are modelled assuming a linear-elastic transversely isotropic material behaviour [22]. The interfaces between the $90^{\circ}$ ply and the homogenised plies are simulated using cohesive elements [22, 42]. The thickness of each individual outer ply is kept constant and equal to $0.075 \mathrm{~mm}$ throughout the analysis. The elastic and interlaminar properties of the IM7/8552 carbon-epoxy composite laminate [45-48] are used to model the elastic response of the outer plies and interlaminar damage between adjacent plies [22]. The relevant material properties of all constituents are given in tables 1 to 3 .

Linear hexahedral FEs with reduced integration (Abaqus ${ }^{\circledR}$ C3D8R elements) are used to generate the mesh of both matrix and fibres of the transverse ply RVE. However, due to the complexity of the geometry, hex- 
ahedral FEs alone could not be used to generate the RVE of the transverse ply, as some elements become excessively distorted. In those cases, following Melro et al. [41], the linear hexahedral FEs are replaced by linear wedge FEs (Abaqus ${ }^{\circledR}$ C3D6 elements). To model the interface between fibres and matrix, 8-node cohesive elements (Abaqus ${ }^{\circledR}$ COH3D8 elements) are used $[22,41]$. Abaqus ${ }^{\circledR}$ C3D8R elements are also used to generate the mesh of the homogenised outer plies, and Abaqus ${ }^{\circledR}$ COH3D8 cohesive elements are used to model the interfaces between adjacent plies.

PBCs are applied to the thin-ply sublaminate RVEs in the $x x$ - and $y y$ directions [22], imposed through linear multi-point constraints [41]. In the present work, only transverse compressive loading is considered. The effect of residual thermal stresses is not taken into account, since the focus of the present study is on the effect of ply thickness on the mechanical response of constrained transverse plies for validation of the theory and current analytical models for the in situ effect in compression. The rationale followed here is consistent with the use of the in situ strengths in models of homogenised composite materials. In such models, the in situ strength is taken as a material and geometrical property and the different residual stresses resulting from different ply thickness are calculated from a stress analysis model. Therefore, including residual stresses in the micro-mechanical models could not allow a comparison between these models and the simple, closed-form solutions for the in situ effect. 


\section{Results}

To validate the present framework, the strain field distribution along the transverse $(y y-)$ direction was evaluated. It could be observed that the present micro-mechanical simulations fully agree with the experimental observations carried out by Canal et al. [49], with fibres showing a very homogeneous strain field, whereas the matrix showed a very inhomogeneous strain distribution. This preliminary observation, together with the analysis carried out by Melro et al. [41] and Arteiro et al. [22], confirm the validity of the present framework, namely for studying the in situ effect observed on the response to transverse compressive loading of polymer composite laminates.

Figures 3 to 5 show the contour plots of the equivalent plastic strain in the matrix of RVEs with ultra-thin and conventional $90^{\circ}$ plies at applied strains of $2.0 \%$ and $2.5 \%$. Although only one RVE is presented for each case, the selected RVEs are representative of other random fibre distributions.

As can be observed in figure 5 for cross-ply sublaminates with conventional, standard-thickness $90^{\circ}$ plies, failure caused by transverse compressive loading is dominated by fibre-matrix interface cracking and large localised plastic deformation of the matrix, forming a localised band of damage in a plane not aligned with the loading direction. This wedge shaped transverse fracture is in agreement with what has been described in the literature $[41,50]$. In the case of cross-ply sublaminates with ultra-thin plies, a similar damage pattern can be identified, but developing at higher applied strains, as shown in figures 3 and 4 . In fact, looking at these pictures, and comparing them with figure 5, a transverse crack suppression effect can be clearly identified. As the ply thickness decreases, damage progression becomes more 
and more gradual, and through-the-thickness fracture is delayed. This fact indicates that there is an in situ effect in transverse compression.

Figures 6 and 7 show the contour plots of the equivalent plastic strain in the matrix of RVEs with, respectively, $0.020 \mathrm{~mm}$ and $0.060 \mathrm{~mm}$ thick $90^{\circ}$ plies at applied strains ranging from $3.0 \%$ to $4.0 \%$. Unlike conventional $90^{\circ}$ plies subjected to transverse compressive loading (figure 5), whose fracture is characterised by a wedge shaped transverse crack, constrained ultra-thin plies show a dispersed damage mechanism, combining wedge cracking with ply fragmentation/separation, or just ply fragmentation/separation, as in the case of the thinnest plies (see figure 8). This dispersed type of damage observed on thin-ply sublaminates is the result of a less pronounced stress relaxation due to the constraining effect imposed by the surrounding plies, causing the development of progressive, overall ply damage instead of discrete transverse cracking. This constraining effect, and how it affects stress relaxation in the transverse ply, is further highlighted in figure 9, which shows the stress distributions predicted for RVEs with $0.060 \mathrm{~mm}$ and $0.120 \mathrm{~mm}$ thick $90^{\circ}$ plies. Upon onset of transverse damage, the stress relaxation is much higher in the thicker transverse plies than in the thinner ones. This happens because the constraining effect imposed by the adjacent plies on the thicker transverse plies is not sufficient to delay transverse damage growth through the thickness. On the other hand, the higher stress levels maintained on the thinner transverse plies, which results from the higher constraining effect imposed by adjacent plies on damage propagation through the thickness, conducts to diffuse transverse damage onset and growth before earlier damage has penetrated. 
Figure 10 shows the in situ transverse compressive strength, $Y_{C}^{i s}$, as a function of the ply thickness determined from the micro-mechanical models presented in this work, and the predictions from the models for the in situ transverse compressive strength proposed by Catalanotti et al. [36] and, more recently, by Camanho et al. [37]. For some ply thicknesses, several RVEs have been analysed, and the respective data has been plotted in figure 10. The in situ strengths from the micro-mechanical models were calculated based on the applied remote strain corresponding to the development of through-the-thickness ply failure, characterised by a localised band of damage, as described before, and based on the elastic properties determined from a linear-elastic analysis of the same RVE. Notice that, in the case of the thinner sublaminates, the development of the first through-the-thickness band of damage is delayed, and other regions of localised damage start propagating before failure of the thin transverse ply has occurred. Unless one of these localised bands penetrates completely through the ply thickness, the transverse ply is not considered to have failed. As the ply thickness decreases, the number of localised bands increases, but one eventually will be the first to penetrate through the thickness. That is the point that defines the strength of the thinner transverse plies. It is interesting to note that, once the first band penetrates through the thickness, the remaining will also penetrate progressively.

According to Catalanotti et al. [36], the in situ transverse compressive strength, $Y_{C}^{i s}$, is given explicitly as:

$$
Y_{C}^{i s}=\frac{S_{L}^{i s}\left(2 \cos ^{2} \alpha_{0}-1\right)}{\eta_{L} \cos ^{2} \alpha_{0}}
$$


where $\alpha_{0}$ is the fracture angle and $\eta_{L}$ is the friction coefficient [36]. The in situ in-plane shear strength, $S_{L}^{i s}$, is calculated from the fracture mechanics model proposed by Camanho et al. [33]:

$$
S_{L}^{i s}=\sqrt{\frac{\left(1+\beta \phi G_{12}^{2}\right)^{1 / 2}-1}{3 \beta G_{12}}}
$$

where $\beta$ is a parameter that defines the nonlinearity of the shear stress-shear strain relation [51], $G_{12}$ is the shear modulus and the parameter $\phi$ is defined according to the configuration of a given ply. For a thick ply, $\phi$ is given as [33]:

$$
\phi=\frac{12 S_{L}^{2}}{G_{12}}+18 \beta S_{L}^{4}
$$

and, for a thin ply [33]:

$$
\phi=\frac{48 \mathcal{G}_{I I c}}{\pi b}
$$

where $\mathcal{G}_{I I c}$ is the fracture toughness associated with intralaminar fracture of the transverse ply (parallel to the fibre direction) in mode II. According to Camanho et al. [37], the in situ transverse compressive, transverse shear $\left(S_{T}^{i s}\right)$ and biaxial transverse tensile $\left(Y_{B T}^{i s}\right)$ strengths are calculated numerically assuming that the slopes in the $\sigma_{22}-\sigma_{12}$ and $\sigma_{22}-\sigma_{23}$ failure envelopes when $\sigma_{22}=0$ are not in situ properties - see figure 11 - and assuming that the biaxial transverse compressive strength is not an in situ property $\left(Y_{B C}=\right.$ $\left.Y_{B C}^{i s}\right)$, whereas the in situ transverse tensile $\left(Y_{T}^{i s}\right)$ and in-plane shear strengths $\left(S_{L}^{i s}\right.$ - equation $\left.(2)\right)$ are calculated using the fracture mechanics models proposed by Camanho et al. [33]. 
The strength and elastic properties required by the analytical models were determined from a separate analysis of the micro-mechanical computational model using UD RVEs, following Melro et al. [41]. The micromechanical simulations included pure transverse tension and compression, transverse shear and in-plane longitudinal shear stress states. The biaxial transverse tensile and compressive strengths ( $Y_{B T}$ and $Y_{B C}$, respectively) were estimated based on the approach suggested by Vogler et al. [52]. As a first approximation, the fracture toughness associated with intralaminar fracture of the transverse ply (parallel to the fibre direction) was taken as $25 \%$ of the fracture toughness of the matrix for mode 1 , and $50 \%$ of the fracture toughness of the matrix for mode II (or twice the fracture toughness for mode I). The parameter $\beta$ was determined based on the results from the micro-mechanical computational model of UD RVEs subjected to pure inplane longitudinal shear, fitting the polynomial approximation proposed by Hahn and Tsai [51], given in equation (5), to the shear stress-shear strain curves obtained with three different RVEs.

$$
\gamma_{12}=\frac{1}{G_{12}} \sigma_{12}+\beta \sigma_{12}^{3}
$$

For the model proposed by Catalanotti et al. [36], the fracture angle and the friction coefficient were assumed as $\alpha_{0}=53^{\circ}$ and $\eta_{L}=0.36$, respectively. Table 4 shows the properties of the UD material used in the analytical models proposed in Refs. $[33,36,37]$ to calculate the in situ properties.

Comparing the predictions of the in situ effect for transverse compression with the results obtained using computational micro-mechanics in figure 10, similar trends are observed, which indicates that the analytical models are 
sufficiently accurate, and that there is an in situ effect in the transverse compressive failure of polymer composites. To the authors' knowledge, this is the first time an in situ effect in transverse compression has been clearly identified, and the validity of the analytical models proposed in Refs. [36, 37] to predict this in situ effect demonstrated.

Figure 10 also shows that the predicted in situ transverse compressive strengths for ply thicknesses above $0.060 \mathrm{~mm}$ are very similar, in agreement with the available theoretical models for the in situ effect. This observation validates the results of the models with ply thicknesses above $0.100 \mathrm{~mm}$, with $0.120 \mathrm{~mm}$ wide RVEs, defined to accommodate approximately a single transverse crack, and for which diffuse damage is very limited before transverse crack growth through the thickness. This observation also shows that these models may not benefit from a wider RVE, as suggested in section 2 .

\section{Discussion and concluding remarks}

In this work, a detailed representation of the mechanics of transverse compressive failure and associated in situ effect has been studied using a 3D computational micro-mechanics framework [22, 40, 41]. For cross-ply sublaminates with conventional, standard-thickness $90^{\circ}$ plies, failure was dominated by fibre-matrix interface cracking and large localised plastic deformation of the matrix, forming a localised band of damage in a plane not aligned with the loading direction. The predicted wedge shaped transverse fracture is in agreement with what has been described in the literature $[41,50]$. Unlike conventional $90^{\circ}$ plies subjected to transverse compressive loading, constrained ultra-thin plies showed a dispersed damage mechanism, combining 
wedge cracking with ply fragmentation/separation, or just ply fragmentation/separation for the thinnest plies. This dispersed type of damage on thin-ply sublaminates is the result of a less pronounced stress relaxation due to the stronger constraining effect imposed by the surrounding plies. This results in the development of progressive ply damage instead of discrete transverse cracking. Therefore, a transverse crack suppression effect could be observed.

It should be noted that, while there is no direct experimental evidence of the in situ effect for transverse compression, some recent test results obtained in structural details indicate that indeed the ply thickness affects the compressive strengths. For example, recent results show that the bearing strength increases with decreasing ply thickness [21]. This observation can be justified by the increase of the transverse and longitudinal compressive strengths of thin-ply laminates.

When comparing the results of the computational micro-mechanics framework with the predictions from the analytical models based on LEFM [33] and on $3 \mathrm{D}$ phenomenological failure criteria $[36,37]$, the same trends have been obtained, emphasising the validity of the computational micro-mechanics and analytical representations. The present results also show that, for normal ply thicknesses, these analytical models can be considered fairly accurate and representative of the actual strengths characterising the response of transverse plies embedded in multidirectional laminates.

Ongoing work is considering the application of the present methodology to the cases of in-plane shear and transverse shear stress states. The cases of biaxial tensile and compressive loading will also be addressed in the future, 
as well as the effect of the stiffness of the adjacent plies and ply position in the laminate.

\section{Acknowledgements}

This work was funded by AIRBUS under project 2genComp — second generation Composites. The authors gratefully acknowledge the support provided by AIRBUS.

The first author is also grateful to Fundação para a Ciência e a Tecnologia (FCT), grant SFRH/BD/88593/2012, funded by Programa Operacional Potencial Humano/Fundo Social Europeu (POPH/FSE). The second author would like to thank project NORTE-07-024-FEDER-000033 - Composite Ma-

terials, Structures and Processes, within the Portuguese National Strategic Reference Framework (QREN), through the European Regional Development Fund (ERDF).

\section{References}

\section{References}

[1] K. Kawabe, T. Matsuo, Z. Maekawa, New technology for opening various reinforcing fiber tows, J Soc Mat Sci Jpn 47 (7) (1998) 727-734, in Japanese.

[2] K. Kawabe, New spreading technology for carbon fiber tow and its application to composite materials, Sen-i Gakkaishi 64 (8) (2008) 262-267, in Japanese. 
[3] H. Sasayama, K. Kawabe, S. Tomoda, I. O. K. K. N. Ogata, Effect of lamina thickness on first ply failure in multidirectionally laminated composites, J Jpn Soc Compos Mater 30 (4) (2004) 142-148, in Japanese.

[4] Y. Nishikawa, K. Okubo, T. Fujii, K. Kawabe, Fatigue crack constraint in plain-woven CFRP using newly-developed spread tows, Int J Fatigue 28 (2006) 1248-1253.

[5] S. Sihn, R. Y. Kim, K. Kawabe, S. W. Tsai, Experimental studies of thin-ply laminated composites, Compos Sci Technol 67 (2007) 996-1008.

[6] K. Kawabe, H. Sasayama, K. Kageyama, N. Ogata, Effect of ply thickness on compressive properties in multidirectionally laminated composites, J Jpn Soc Compos Mater 34 (2008) 173-181, in Japanese.

[7] T. Yokozeki, Y. Aoki, T. Ogasawara, Experimental characterization of strength and damage resistance properties of thin-ply carbon fiber/toughened epoxy laminates, Compos Struct 82 (2008) 382-389.

[8] T. Yokozeki, A. Kuroda, A. Yoshimura, T. Ogasawara, T. Aoki, Damage characterization in thin-ply composite laminates under out-of-plane transverse loading, Compos Struct 93 (2010) 49-57.

[9] J.-B. Moon, M.-G. Kim, C.-G. Kim, S. Bhowmik, Improvement of tensile properties of CFRP composites under LEO space environment by applying MWNTs and thin-ply, Compos Part A-Appl S 42 (2011) 694701.

[10] H. Saito, M. Morita, K. Kawabe, M. Kanesaki, H. Takeuchi, M. Tanaka, 
I. Kimpara, Effect of ply-thickness on impact damage morphology in CFRP laminates, J Reinf Plast Comp 30 (2011) 1097-1106.

[11] H. Saito, H. Takeuchi, I. Kimpara, Experimental evaluation of the damage growth restraining in $90^{\circ}$ layer of thin-ply CFRP cross-ply laminates, Adv Compos Mater 21 (2012) 57-66.

[12] H. M. El-Dessouky, C. A. Lawrence, T. McGrail, W. R. Broughton, Ultra-lightweight carbon fibre/thermoplastic composite material using spread tow technology, Compos Part B-Eng 50 (2013) 91-97.

[13] A. Arteiro, G. Catalanotti, J. Xavier, P. P. Camanho, Notched response of non-crimp fabric thin-ply laminates, Compos Sci Technol 79 (2013) 97-114.

[14] G. Czél, M. R. Wisnom, Demonstration of pseudo-ductility in high performance glass/epoxy composites by hybridisation with thin-ply carbon prepreg, Compos Part A-Appl S 52 (2013) 23-30.

[15] A. Arteiro, G. Catalanotti, J. Xavier, P. P. Camanho, Notched response of non-crimp fabric thin-ply laminates: Analysis methods, Compos Sci Technol 88 (2013) 165-171.

[16] P. Linde, N. Heltsch, T. Kruse, S. Das, C. Vernier, Second generation composites, in: 19. Nationales Symposium — SAMPE Deutschland E. V., Hamburg, 2013, pp. 1-2, in German.

[17] A. Kuraishi, T. Itoh, J. Kimoto, S. Ochi, N. Hirano, Applicability of C-ply Bi-angle ${ }^{\mathrm{TM}}$ NCF to aircraft parts, in: Proceedings of ICCM-19, Montréal, 2013, pp. 1-11. 
[18] D. S. A. Cadena, Improvement in damage tolerance and buckling behaviour of a composite fuselage panel using thin plies, Master's thesis, Politecnico de Milano, Facoltà di Ingegneria Industriale, Milan (2014).

[19] A. Arteiro, G. Catalanotti, J. Xavier, P. P. Camanho, Large damage capability of non-crimp fabric thin-ply laminates, Compos Part A-Appl S 63 (2014) 110-122.

[20] G. Guillamet, A. Turon, J. Costa, J. Renart, P. Linde, J. A. Mayugo, Damage occurrence at edges of non-crimp-fabric thin-ply laminates under off-axis uniaxial loading, Compos Sci Technol 98 (2014) 44-50.

[21] R. Amacher, J. Cugnoni, J. Botsis, L. Sorensen, W. Smith, C. Dransfeld, Thin ply composites: Experimental characterization and modeling of size-effects, Compos Sci Technol 101 (2014) 121-132.

[22] A. Arteiro, G. Catalanotti, A. R. Melro, P. Linde, P. P. Camanho, Micromechanical analysis of the in situ effect in polymer composite laminates, Compos Struct 116 (2014) 827-840.

[23] C. Baley, M. Lan, P. Davies, D. Cartié, Porosity in ocean racing yacht composites: a review, Appl Compos Mater 22 (2015) 13-28.

[24] J. Fuller, M. R. Wisnom, Pseudo-ductility and damage suppression in thin ply CFRP angle-ply laminates, Compos Part A-Appl S 69 (2015) $64-71$.

[25] R. Olsson, Analytical prediction of damage due to large mass impact on thin ply composites, Compos Part A-Appl S 72 (2015) 184-191. 
[26] H. Saito, H. Takeuchi, I. Kimpara, A study of crack suppression mechanism of thin-ply carbon-fiber-reinforced polymer laminate with mesoscopic numerical simulation, J Compos Mater 48 (17) (2014) 2085-2096.

[27] K. W. Garrett and J. E. Bailey, Multiple transverse fracture in $90^{\circ}$ cross-ply laminates of a glass fibre-reinforced polyester, J Mater Sci 12 (1977) 157-168.

[28] A. Parvizi and K. W. Garrett and J. E. Bailey, Constrained cracking in glass fibre-reinforced epoxy cross-ply laminates, J Mater Sci 13 (1978) 195-201.

[29] A. Parvizi and J. E. Bailey, On multiple transverse cracking in glass fibre epoxy cross-ply laminates, J Mater Sci 13 (1978) 2131-2136.

[30] D. L. Flaggs, M. H. Kural, Experimental determination of the in situ transverse lamina strength in graphite/epoxy laminates, J Compos Mater 16 (1982) 103-116.

[31] F.-K. Chang and M.-H. Chen, The in situ ply shear strength distribution in graphite/epoxy laminated composites, J Compos Mater 21 (1987) 708-733.

[32] L. Boniface and P. A. Smith and M. G. Bader, Transverse ply cracking in cross-ply CFRP laminates - Initiation or propagation controlled?, J Compos Mater 31 (11) (1997) 1080-1112.

[33] P. P. Camanho, C. G. Dávila, S. T. Pinho, L. Iannucci, P. Robinson, Prediction of in situ strengths and matrix cracking in composites under 
transverse tension and in-plane shear, Compos Part A-Appl S 37 (2006) $165-176$.

[34] E. Abisset, F. Daghia, P. Ladevèze, On the validation of a damage mesomodel for laminated composites by means of open-hole tensile tests on quasi-isotropic laminates, Compos Part A-Appl S 42 (2011) 1515 1524 .

[35] T. A. Sebaey and J. Costa and P. Maimí and Y. Batista and N. Blanco and J. A. Mayugo, Measurement of the in situ transverse tensile strength of composite plies by means of the real time monitoring of microcracking, Compos Part B-Eng 65 (2014) 40-46.

[36] G. Catalanotti, P. P. Camanho, A. T. Marques, Three-dimensional failure criteria for fiber-reinforced laminates, Compos Struct 95 (2013) 6379.

[37] P. P. Camanho, A. Arteiro, A. R. Melro, G. Catalanotti, M. Vogler, Three-dimensional invariant-based failure criteria for transversely isotropic fibre-reinforced composites, in: P. P. Camanho, S. R. Hallett (Eds.), Numerical Modelling of Failure in Advanced Composite Materials, Woodhead, 2015, pp. 1-40, in press.

[38] B. Budiansky, N. A. Fleck, J. C. Amazigo, On kink-band propagation in fiber composites, J Mech Phys Solids 46 (9) (1998) 1637-1653.

[39] A. R. Melro, P. P. Camanho, S. T. Pinho, Generation of random distribution of fibres in long-fibre reinforced composites, Compos Sci Technol 68 (2008) 2092-2102. 
[40] A. R. Melro, P. P. Camanho, F. M. A. Pires, S. T. Pinho, Micromechanical analysis of polymer composites reinforced by unidirectional fibres: Part I - Constitutive modelling, Int J Solids Struct 50 (2013) 1897-1905.

[41] A. R. Melro, P. P. Camanho, F. M. A. Pires, S. T. Pinho, Micromechanical analysis of polymer composites reinforced by unidirectional fibres: Part II - Micromechanical analyses, Int J Solids Struct 50 (2013) 1906 1915.

[42] Dassault Systèmes Simulia Corp., Providence, RI, USA, ABAQUS 6.12 Documentation (2012).

[43] Z. P. Bažant, B. H. Oh, Crack band theory for fracture of concrete, Mater Struct 16 (93) (1983) 155-177.

[44] M. Benzeggagh, M. Kenane, Measurement of mixed-mode delamination fracture toughness of unidirectional glass/epoxy composites with mixedmode bending apparatus, Compos Sci Technol 56 (1996) 439-449.

[45] P. P. Camanho, M. Lambert, A design methodology for mechanically fastened joints in laminated composite materials, Compos Sci Technol 66 (2006) 3004-3020.

[46] P. P. Camanho, P. Maimí, C. G. Dávila, Prediction of size effects in notched laminates using continuum damage mechanics, Compos Sci Technol 67 (2007) 2715-2727.

[47] M. R. Wisnom, B. Khan, S. R. Hallett, Size effects in unnotched tensile strength of unidirectional and quasi-isotropic carbon/epoxy composites, Compos Struct 84 (2008) 21-28. 
[48] H. Koerber, J. Xavier, P. P. Camanho, High strain rate characterisation of unidirectional carbon-epoxy IM7-8552 in transverse compression and in-plane shear using digital image correlation, Mech Mater 42 (2010) 1004-1019.

[49] L. P. Canal, C. González, J. M. Molina-Aldareguía, J. Segurado, J. Llorca, Application of digital image correlation at the microscale in fiber-reinforced composites, Compos Part A-Appl S 43 (2012) 16301638.

[50] A. Puck, H. Schürmann, Failure analysis of FRP laminates by means of physically based phenomenological models, Compos Sci Technol 62 (2002) 1633-1662.

[51] H. T. Hahn, S. W. Tsai, Nonlinear elastic shear behavior of unidirectional composite laminae, J Compos Mater 7 (1) (1973) 102-118.

[52] M. Vogler, R. Rolfes, P. P. Camanho, Modeling the inelastic deformation and fracture of polymer composites - Part I: Plasticity model, Mech Mater 59 (2013) $50-64$. 
Table 1: Fibres and matrix material properties.

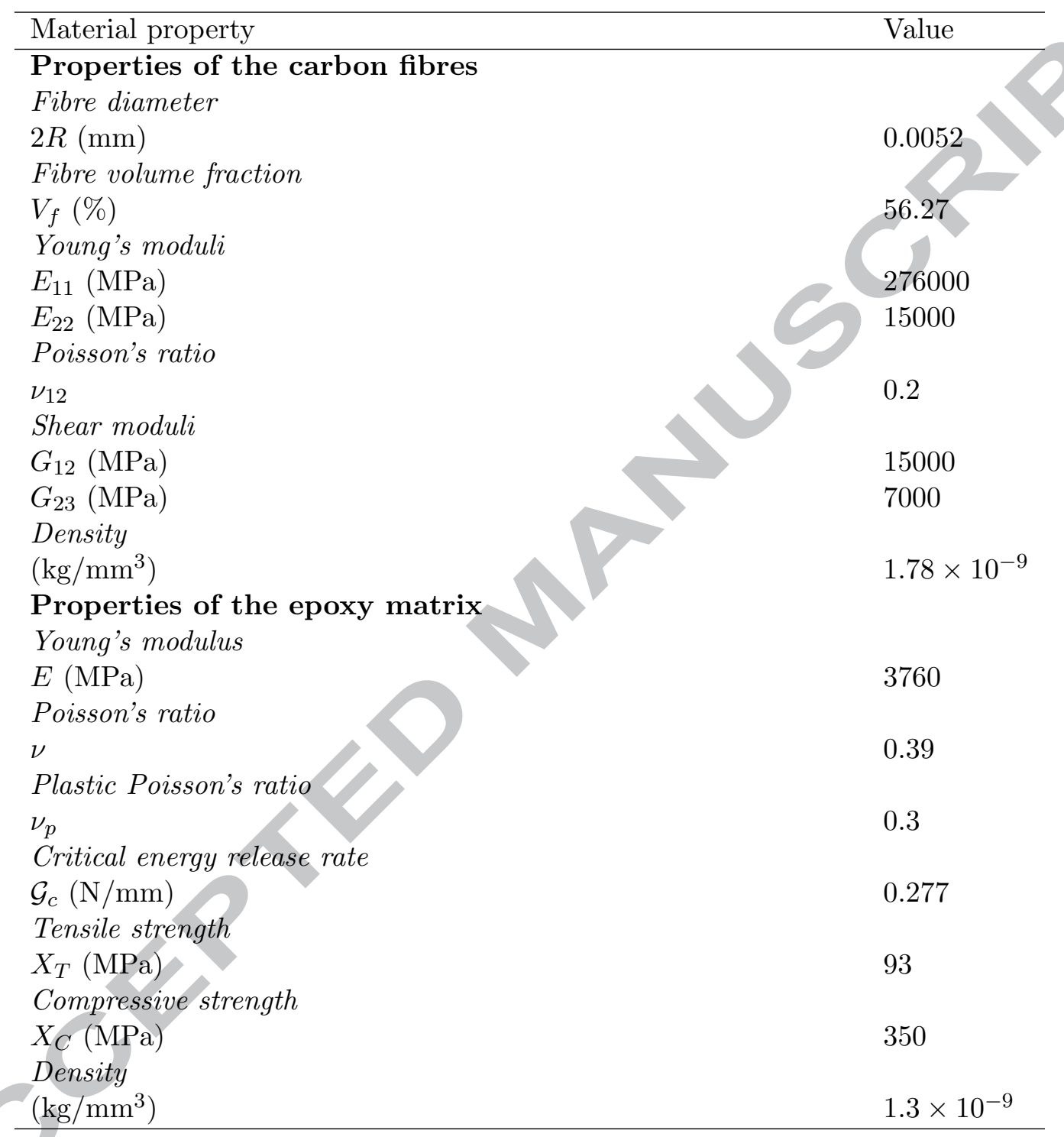


Table 2: Properties of the fibre-matrix interface.

\begin{tabular}{lc}
\hline Material property & Value \\
\hline Interface stiffness & \\
$K\left(\mathrm{~N} / \mathrm{mm}^{3}\right)$ & $10^{8}$ \\
Interface maximum strengths & 75 \\
$\tau_{1}^{0}(\mathrm{MPa})$ & 75 \\
$\tau_{2}^{0}(\mathrm{MPa})$ & 50 \\
$\tau_{3}^{0}(\mathrm{MPa})$ & \\
Interface critical energy release rates & 0.002 \\
$\mathcal{G}_{\text {Ic }}(\mathrm{N} / \mathrm{mm})$ & 0.006 \\
$\mathcal{G}_{I I c}(\mathrm{~N} / \mathrm{mm})$ & 0.006 \\
$\mathcal{G}_{\text {IIIc }}(\mathrm{N} / \mathrm{mm})$ & \\
Mixed-mode interaction parameter $($ BK law $[44])$ & 1.45 \\
$\eta$ & \\
\hline
\end{tabular}

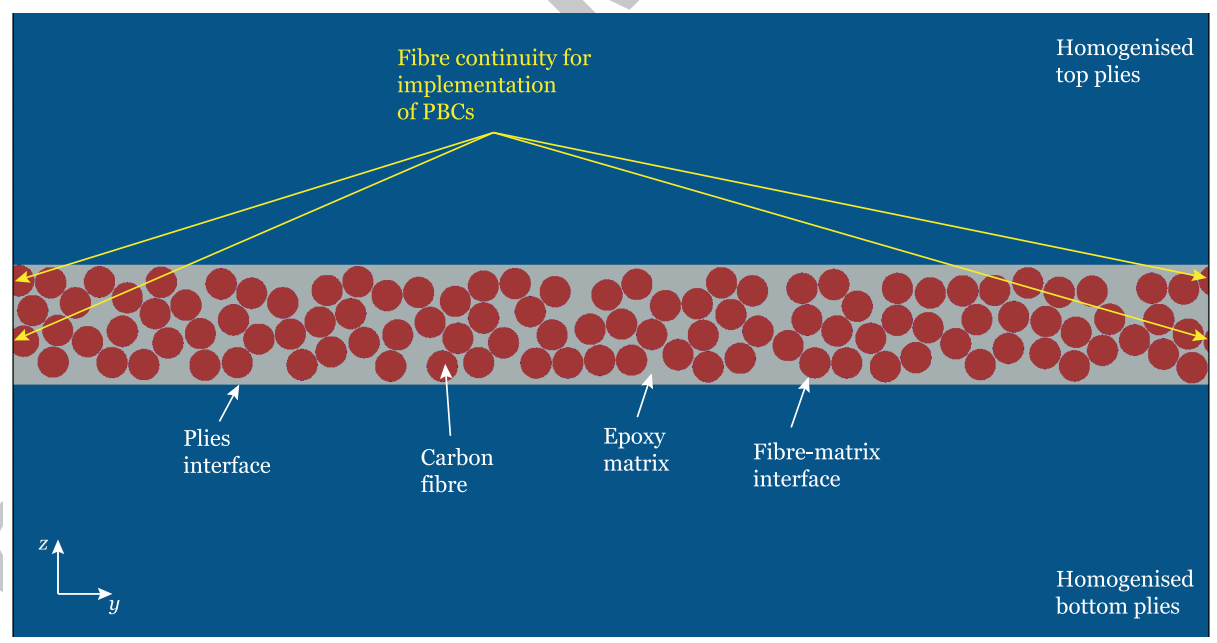

Figure 1: RVE of a laminate with a discrete $0.020 \mathrm{~mm}$ thick $90^{\circ}$ ply. 
Table 3: Properties of the IM7/8552 homogenised ply.

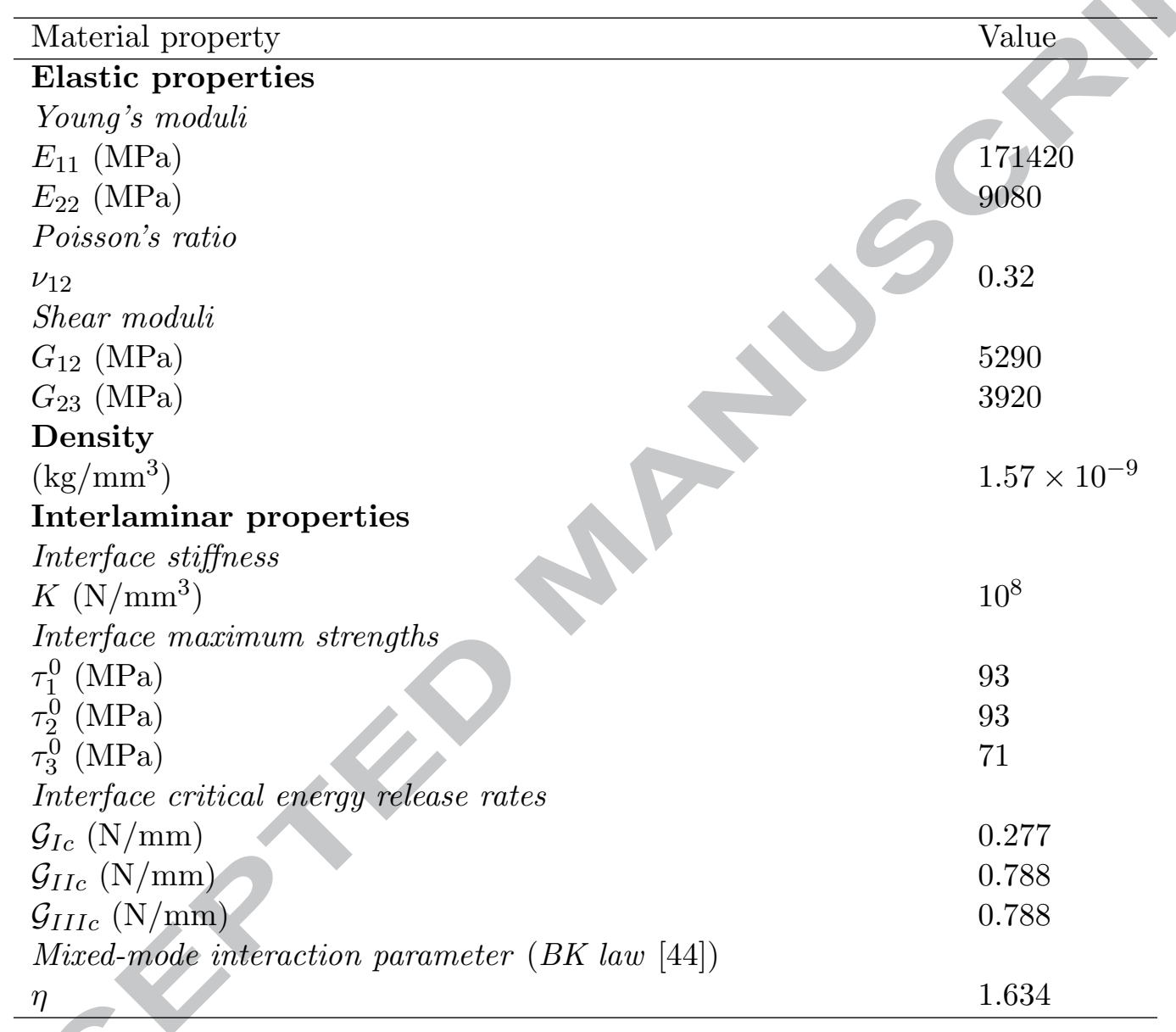




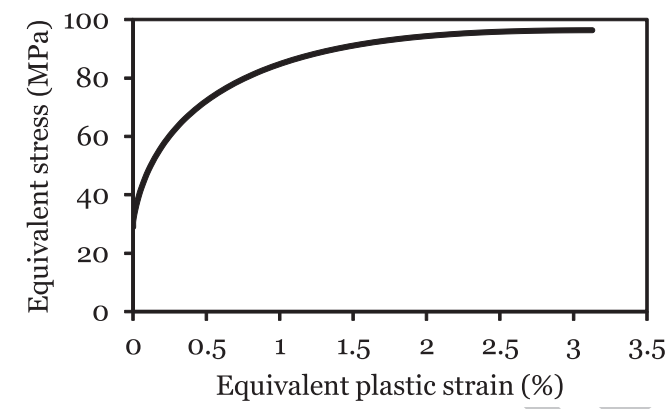

(a) Tensile hardening curve.

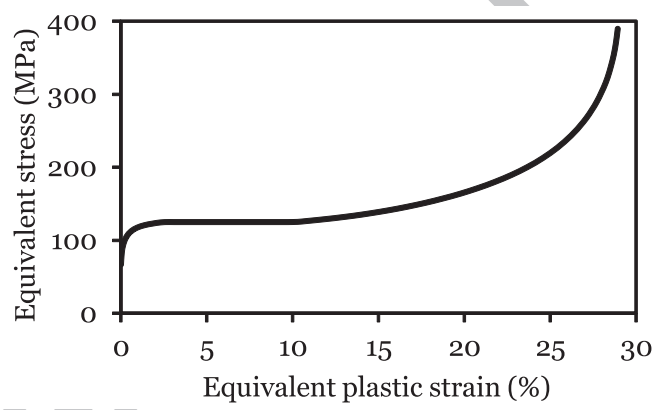

(b) Compressive hardening curve.

Figure 2: Hardening curves used in the plasticity model of the epoxy matrix, given in equivalent stress vs. equivalent plastic strain. 

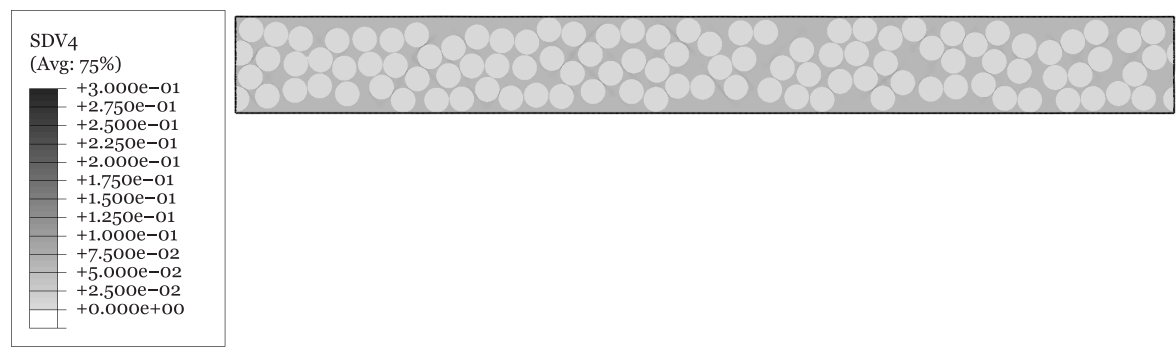

$$
\underset{\mathrm{x}}{\mathrm{Z}} \stackrel{\mathrm{Y}}{\mathrm{P}}
$$

(a) Applied strain of $2.0 \%$.
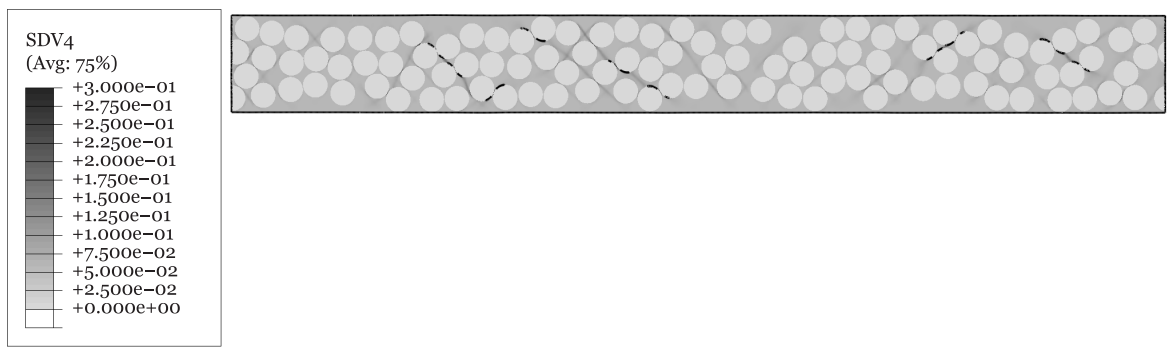

$$
\mathrm{x} \stackrel{\mathrm{L}}{\rightarrow} \mathrm{Y}
$$

(b) Applied strain of $2.5 \%$.

Figure 3: Contour plots of the equivalent plastic strain in the matrix of an RVE with a $0.020 \mathrm{~mm}$ thick $90^{\circ}$ ply, on a sublaminate with $0^{\circ}$ outer plies (only the $90^{\circ}$ ply is shown). 

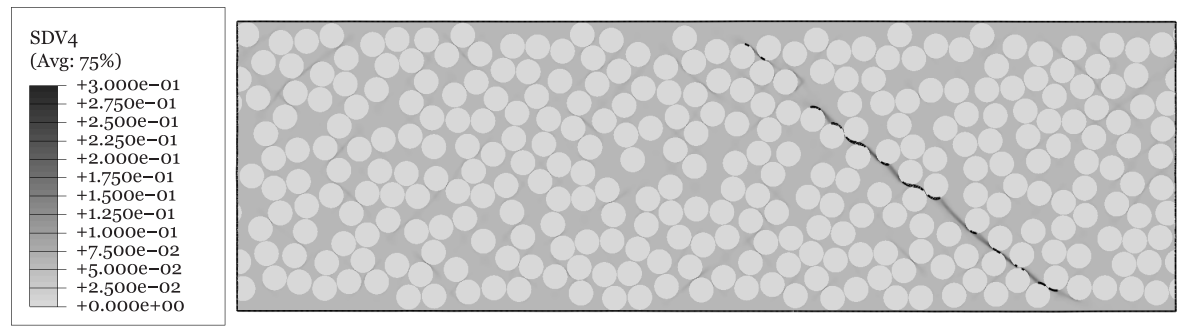

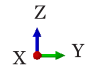

(a) Applied strain of $2.0 \%$.

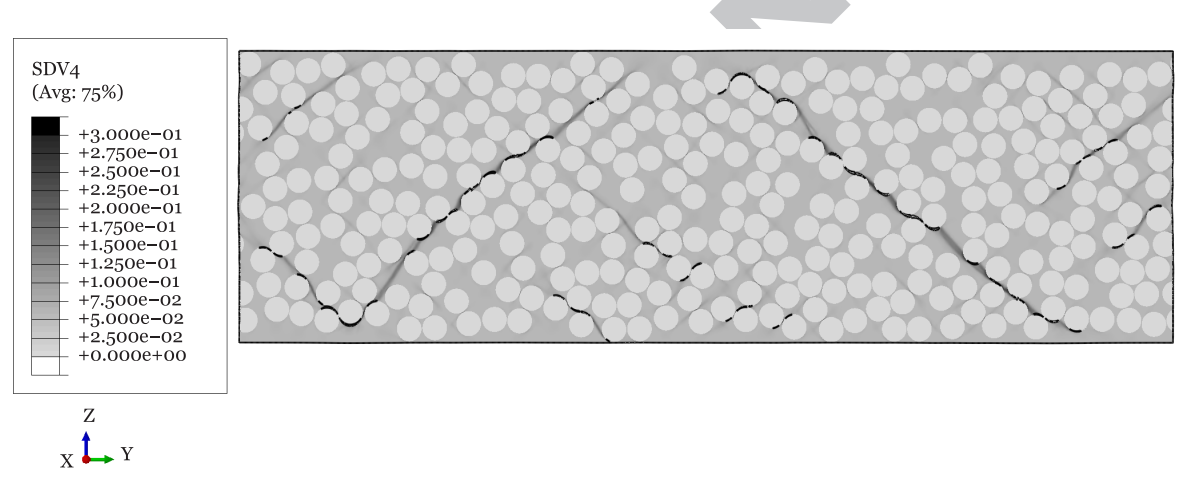

(b) Applied strain of $2.5 \%$.

Figure 4: Contour plots of the equivalent plastic strain in the matrix of an RVE with a $0.060 \mathrm{~mm}$ thick $90^{\circ} \mathrm{ply}$, on a sublaminate with $0^{\circ}$ outer plies (only the $90^{\circ}$ ply is shown). 

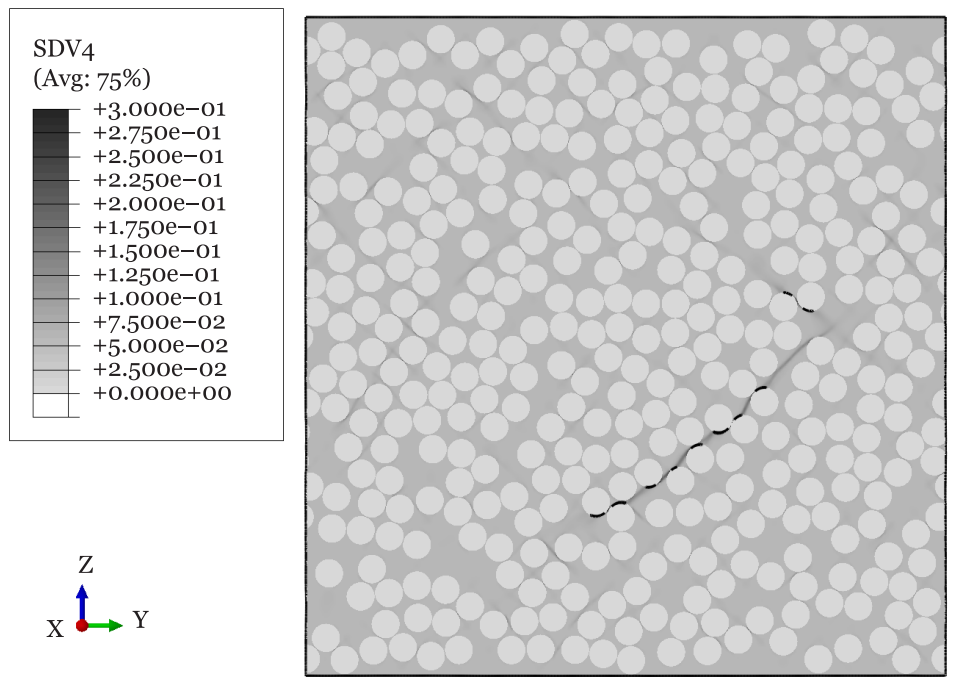

(a) Applied strain of $2.0 \%$.

\section{SDV4 \\ (Avg: $75 \%$ )}

[ $+3.000 \mathrm{e}-\mathrm{O}$

$+2.750 e-01$
$+2.500 e-01$

$+2.500 \mathrm{e}-01$

$+2.250 \mathrm{e}-01$

$+2.000 \mathrm{e}-\mathrm{O}$

$+1.750 \mathrm{e}-01$

$+1.250 \mathrm{e}-01$

$+1.250 \mathrm{O}-01$

$+1.000 \mathrm{e}-01$

$+7.500 \mathrm{e}-02$
$+5.000 \mathrm{e}-02$

$+2.500 \mathrm{e}-02$

$+0.000 \mathrm{e}+00$
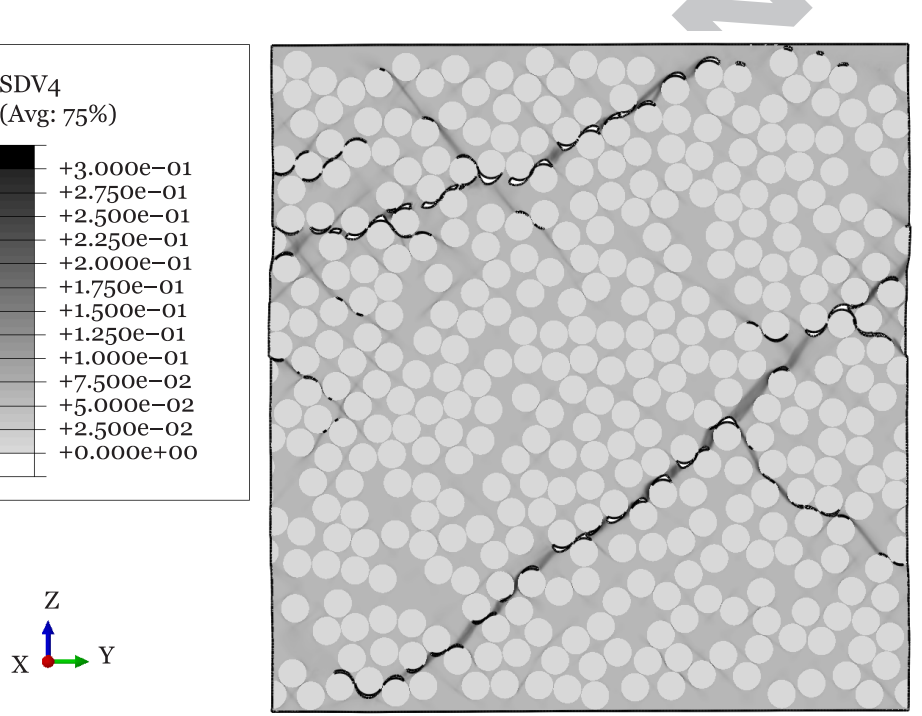

(b) Applied strain of $2.5 \%$.

Figure 5: Contour plots of the equivalent plastic strain in the matrix of an RVE with a $0.120 \mathrm{~mm}$ thick $90^{\circ} \mathrm{ply}$, on a sublaminate with $0^{\circ}$ outer plies (only the $90^{\circ}$ ply is shown). 

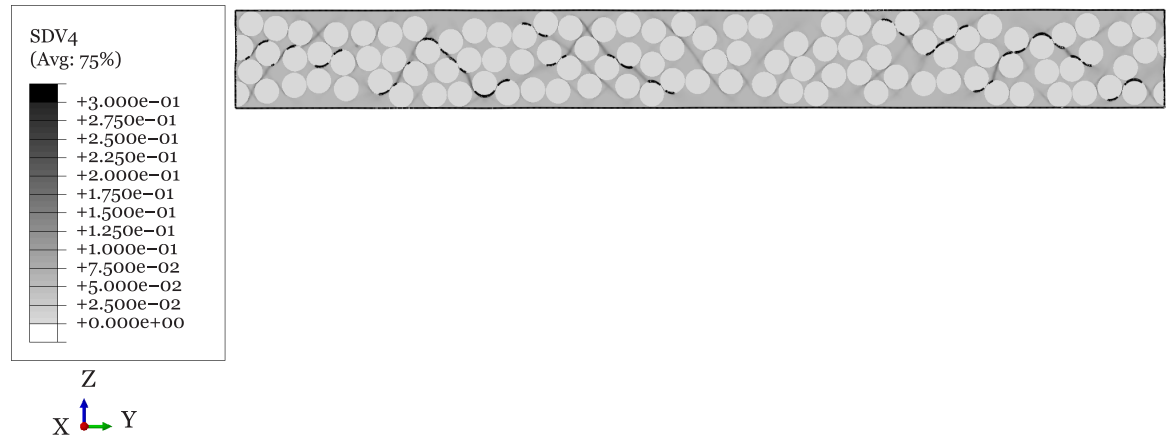

$+2.750 \mathrm{e}-01$

$+2.500 \mathrm{e}-01$

$+2.000 \mathrm{e}-01$

$+1.750 \mathrm{O}-\mathrm{O}$

$+1.250 \mathrm{e}-\mathrm{O}$

$5.500-02$

$\mathrm{x} \stackrel{\llcorner}{\mathrm{Y}}$

(a) Applied strain of $3.0 \%$.
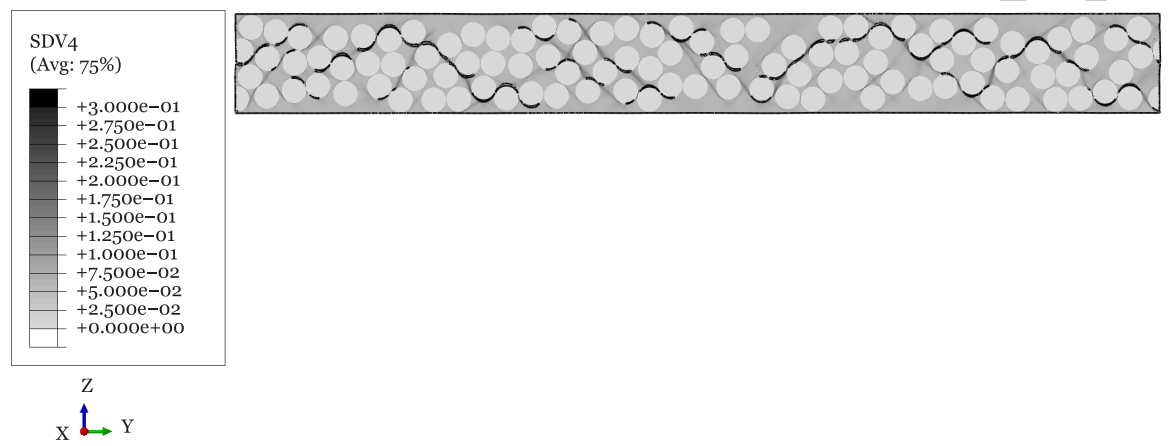

$+2.250 \mathrm{e}-01$

.

. $000 \mathrm{e}-01$

$\mathrm{x} \stackrel{\mathrm{L}}{\mathrm{x}}$

(b) Applied strain of 3.5\%.
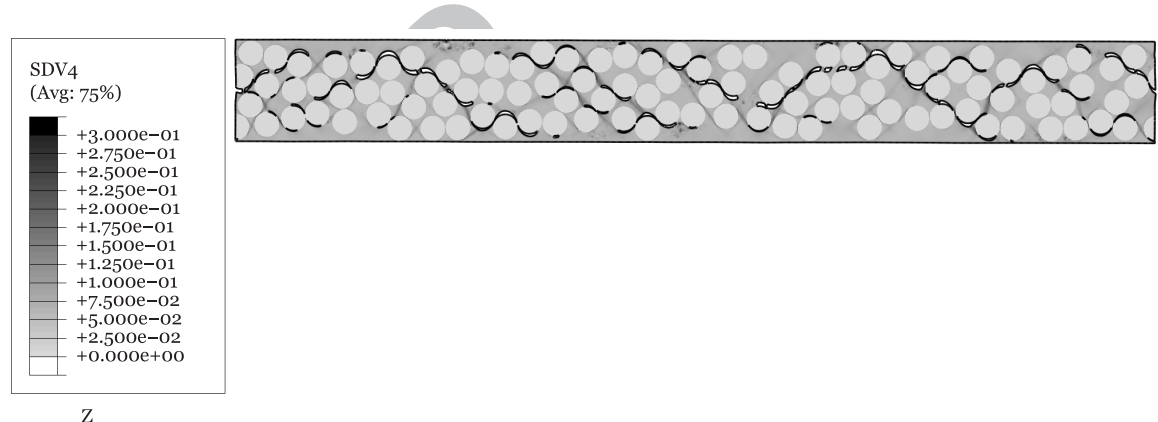

$\mathrm{x} \stackrel{\mathrm{L}}{\rightarrow}$

(c) Applied strain of $4.0 \%$.

Figure 6: Contour plots of the equivalent plastic strain in the matrix of an RVE with a $0.020 \mathrm{~mm}$ thick $90^{\circ}$ ply, on a sublaminate with $0^{\circ}$ outer plies (only the $90^{\circ}$ ply is shown). 

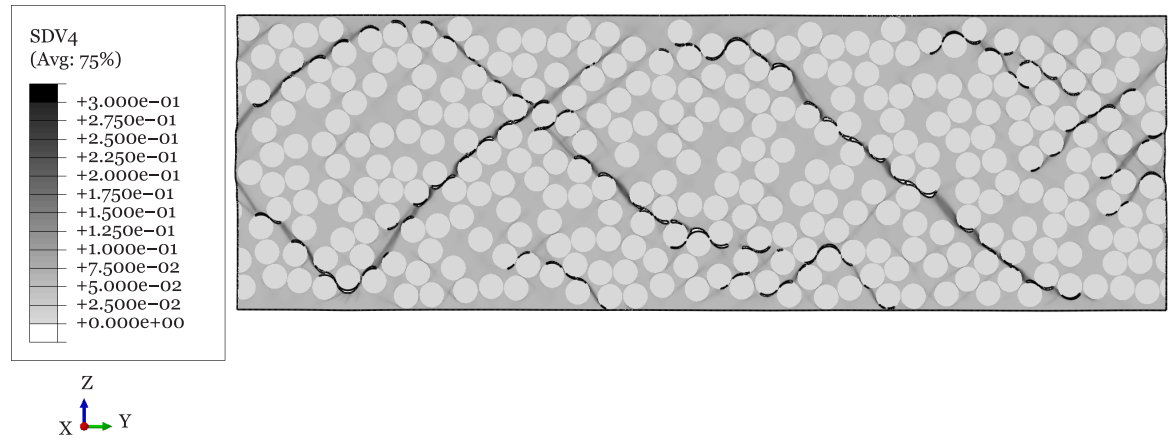

(a) Applied strain of $3.0 \%$.
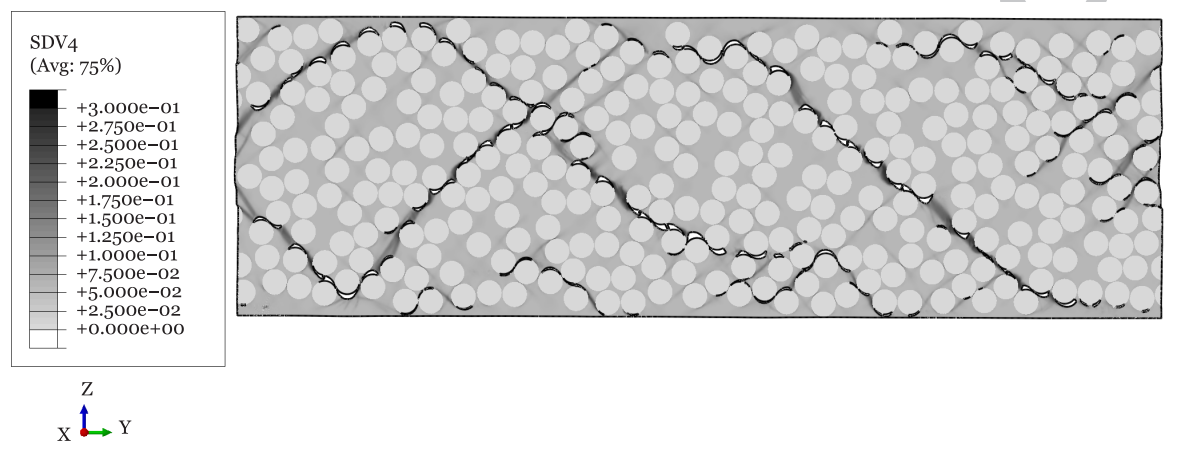

$\underset{\mathrm{L}}{\mathrm{L}} \mathrm{x} \mathrm{Y}$

(b) Applied strain of $3.5 \%$.
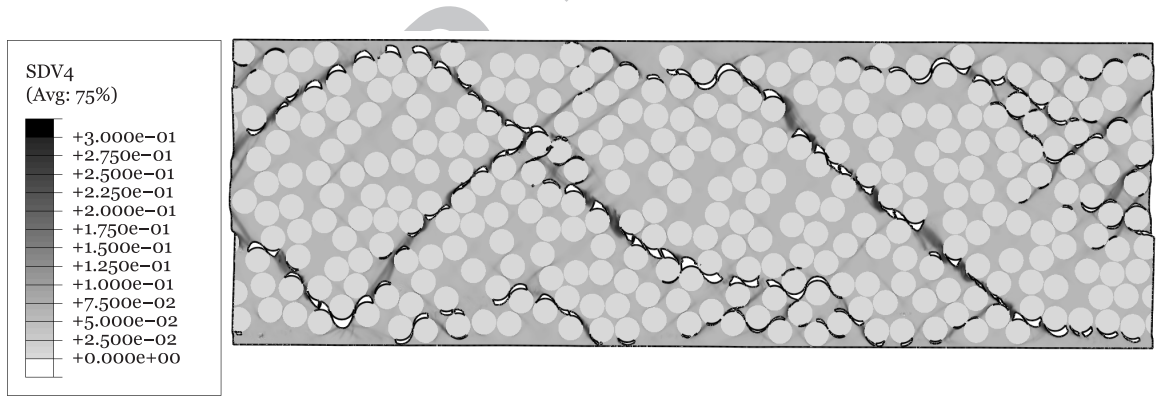

(c) Applied strain of $4.0 \%$.

Figure 7: Contour plots of the equivalent plastic strain in the matrix of an RVE with a $0.060 \mathrm{~mm}$ thick $90^{\circ}$ ply, on a sublaminate with $0^{\circ}$ outer plies (only the $90^{\circ}$ ply is shown). 
Table 4: Properties of the UD material.

\begin{tabular}{lc}
\hline Material property & Value \\
\hline Elastic properties & 152570 \\
$E_{11}(\mathrm{MPa})$ & 8238 \\
$E_{22}(\mathrm{MPa})$ & 4026 \\
$G_{12}(\mathrm{MPa})$ & 0.27 \\
$\nu_{12}(-)$ & \\
Strength properties & 37.3 \\
$Y_{T}(\mathrm{MPa})$ & 23.2 \\
$Y_{B T}(\mathrm{MPa})$ & 147.9 \\
$Y_{C}(\mathrm{MPa})$ & 349.9 \\
$Y_{B C}(\mathrm{MPa})$ & 34.1 \\
$S_{T}(\mathrm{MPa})$ & 61.7 \\
$S_{L}(\mathrm{MPa})$ & \\
Critical energy release rate & 0.069 \\
$\mathcal{G}_{I c}(\mathrm{~N} / \mathrm{mm})$ & 0.139 \\
$\mathcal{G}_{I I c}(\mathrm{~N} / \mathrm{mm})$ & \\
Shear nonlinearity & $3 \times 10^{-8}$ \\
$\beta(\mathrm{MPa}-3)$ & \\
Fracture angle & 53 \\
$\alpha_{0}\left({ }^{\circ}\right)$ & \\
Friction coefficient & 0.36 \\
$\eta_{L}(-)$ & \\
\hline
\end{tabular}




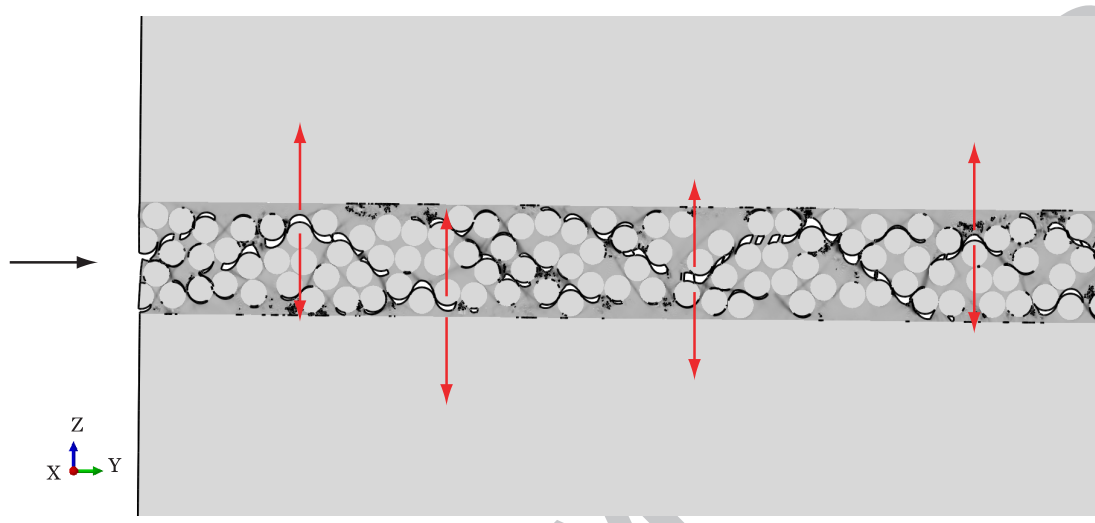

Figure 8: Fragmentation/ply separation of an RVE with a $0.020 \mathrm{~mm}$ thick $90^{\circ}$ lamina subjected to an applied transverse compressive strain of $4.9 \%$, on a sublaminate with $0^{\circ}$ outer plies. The black arrows show the loading direction, and the red arrows indicate the opening movement of the fractured ply. (For interpretation of the references to colour in this figure, the reader is referred to the web version of this article.) 


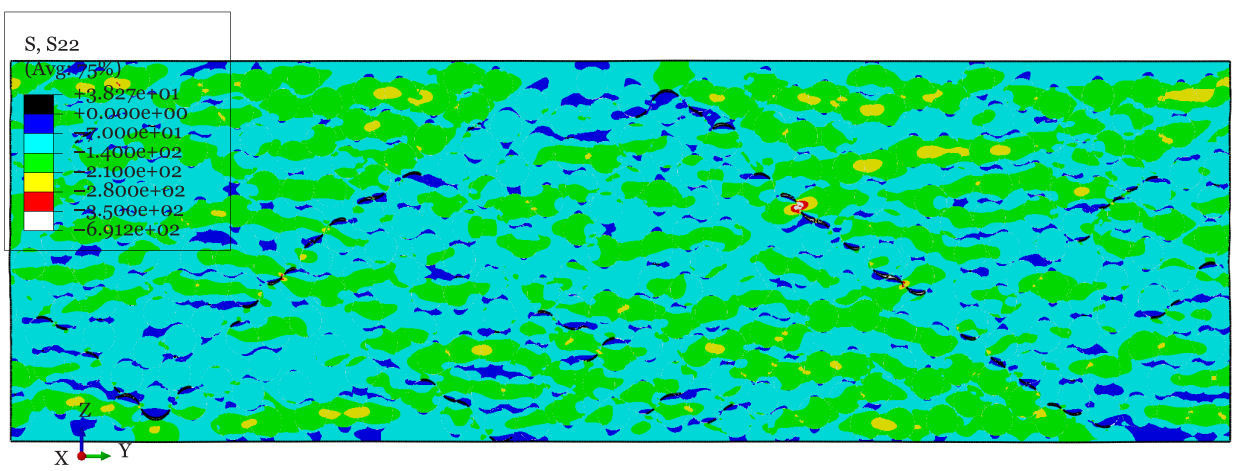

(a) $0.060 \mathrm{~mm}$ thick $90^{\circ}$ ply.
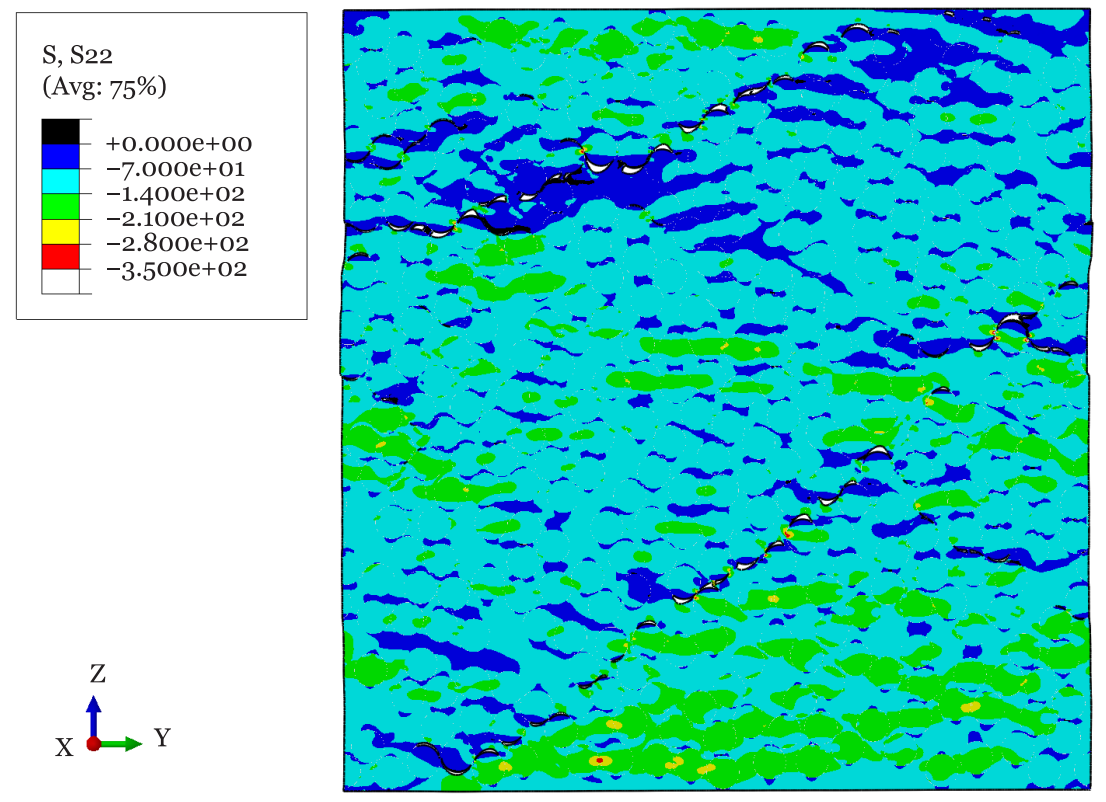

(b) $0.120 \mathrm{~mm}$ thick $90^{\circ}$ ply.

Figure 9: Stress distribution along the transverse (yy-) direction, at an applied transverse compressive strain of $2.5 \%$ (only the $90^{\circ}$ plies are shown). 


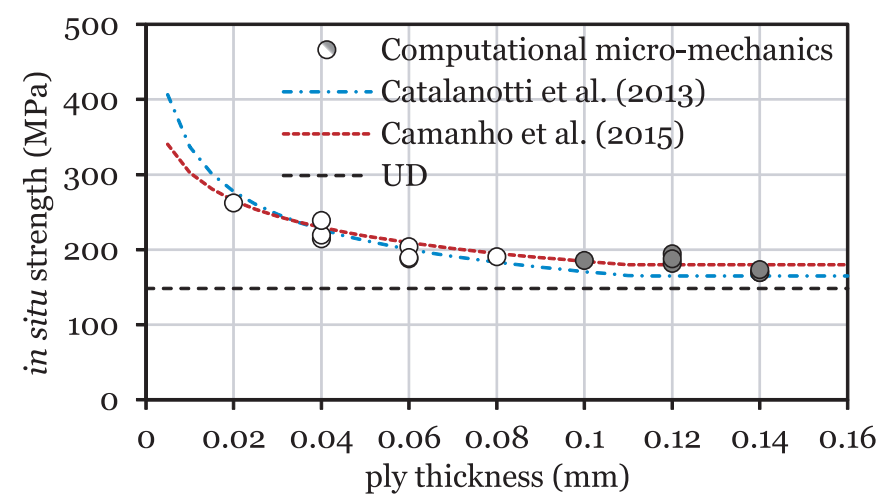

Figure 10: In situ transverse compressive strength as a function of the ply thickness. White and grey filled dots stand for $0.200 \mathrm{~mm}$ and $0.120 \mathrm{~mm}$ wide RVEs, respectively. (For interpretation of the references to colour in this figure, the reader is referred to the web version of this article.)

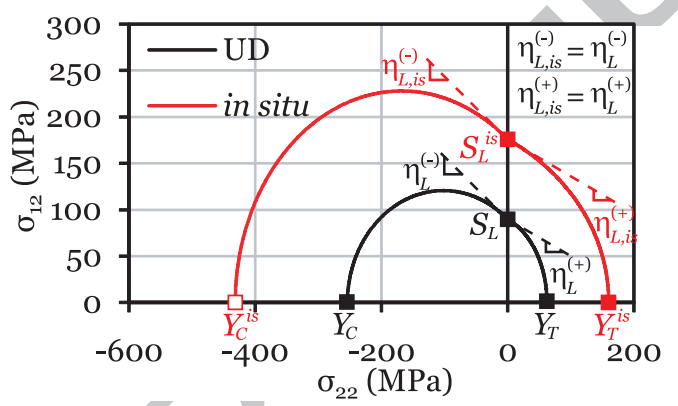

(a) $\sigma_{22}-\sigma_{12}$ failure envelope.

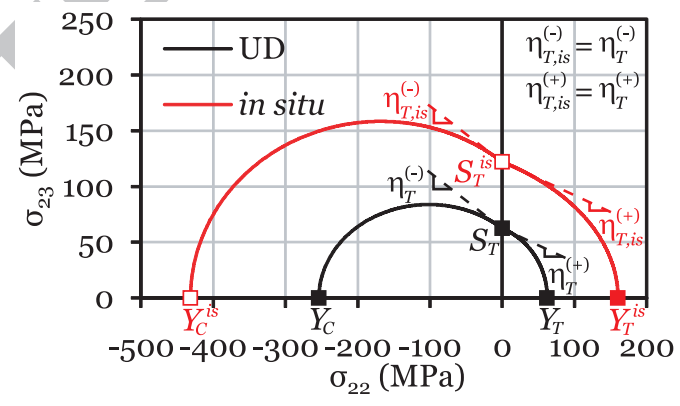

(b) $\sigma_{22}-\sigma_{23}$ failure envelope.

Figure 11: Failure envelopes and assumptions for determination of the in situ strengths following the model proposed by Camanho et al. [37]. 